Archive for

Organic Chemistry

Arkivoc 2018, part v, 0-0

\title{
A new approach to the pyrrolo[3,4-b]indole ring system
}

\author{
Jeanese C. Badenock, Heidi L. Fraser, and Gordon W. Gribble* \\ Department of Chemistry, Dartmouth College, Hanover, NH 03755, USA \\ ggribble@dartmouth.edu
}

\section{Dedicated to the memory of Martin E. Kuehne}

Received 03-27-2018

Accepted 04-26-2018

Published on line 06-11-2018

\section{Abstract}

We report an approach to the pyrrolo[3,4-b]indole ring system that involves a new synthesis of pyrrolo[3,4$b]$ indol-1(2H)ones, which are known precursors to pyrrolo[3,4-b]indoles. 3-Trifluoroacetylindole is prepared from indole and converted into indole carboxamides upon reaction with lithiated amines. Subsequent $\mathrm{C}-2$ bromination followed by a tri- $n$-butyltin hydride induced 1,5-radical translocation and 5-endo-trig cyclization affords 3,4-dihydropyrrolo[3,4-b]indol-1(2H)-one which upon reduction with DIBAL by the method of Kreher gives pyrrolo[3,4-b]indole.<smiles>[R]n1cc2[nH]c3ccccc3c2c1</smiles><smiles>[R]N1Cc2[nH]c3ccccc3c2C1=O</smiles><smiles>C=C</smiles><smiles>[R]N(C)C(=O)c1c[nH]c2ccccc12</smiles><smiles>C=CCCC</smiles><smiles>c1ccc2[nH]ccc2c1</smiles>

Keywords: Indole, pyrrolo[3,4-b]indole, pyrrolo[3,4-b]indolone, amidation, bromination 


\section{Introduction}

In continuation of our interest in the synthesis and chemistry of pyrrolo[3,4-b]indoles, ${ }^{1-6}$ we now describe a new synthesis of the pyrrolo[3,4-b]indole ring system that starts with indole itself. Our previous routes to this ring system utilized a pre-functionalized indole (e.g., 2- and 3-nitroindole, 2,3-dimethylindole). Furthermore, some of the previous syntheses of pyrrolo[3,4-b] indoles by Welch, ${ }^{7}$ Sha, ${ }^{8-10}$ Kreher, ${ }^{11,12}$ Srinivasan, ${ }^{13}$ Snyder, ${ }^{14}$ and Solé ${ }^{15}$ used a Fischer indolization of the appropriate 2,3-pyrrolidinedione or 2,4-pyrrolidinedione ${ }^{16-18}$ to afford the corresponding pyrrolo[3,4-b]indol-3(2H)-one or pyrrolo[3,4-b]indol-1(2H)-one, followed by reduction to the 1,2,3,4-tetrahydropyrrolo[3,4-b]indole or the pyrrolo[3,4-b]indole ring system. $7,11,12$

We envisioned a synthesis of the pyrrolo[3,4-b]indole (1) ring system via the corresponding pyrrolo[3,4b] indol-1(2H)one (2) that could be fashioned from a suitable indole amide (3) via radical methodology (Scheme 1).

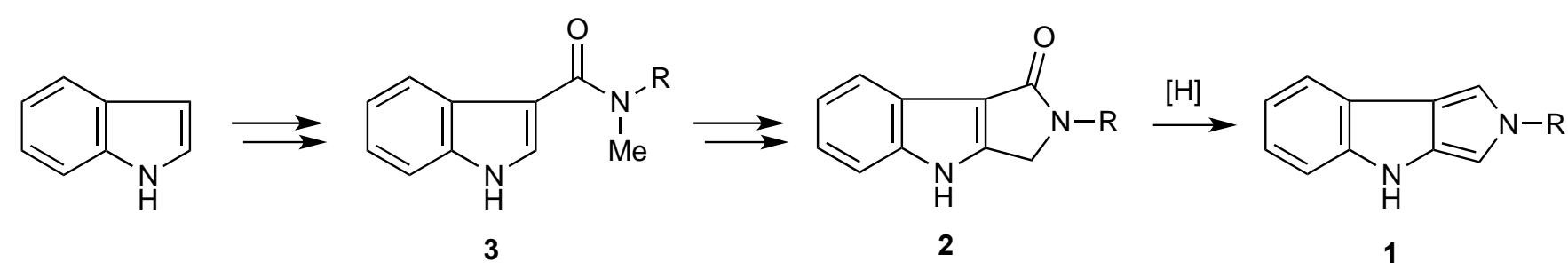

\section{Scheme 1}

\section{Results and Discussion}

Our syntheses of 2-(t-butyl)-3,4-dihydro-4-methylpyrrolo[3,4-b]indol-1(2H)-one (4) and, by reduction, to the corresponding 2-(t-butyl)-2,4-dihydro-4-methylpyrrolo[3,4-b]indole (5), both of which were prepared by Kreher $^{12}$ via a Fischer-indole strategy, are depicted in Schemes 2 and 3 . Indole was trifluoroacetylated to the known 3-trifluoroacetylindole $(6)^{19}$ and then aminated ${ }^{20}$ with the anion of methyl-t-butylamine to afford amide $\mathbf{7}$ in excellent yield. Treatment of $\mathbf{7}$ with sodium hydroxide followed by iodomethane then gave amide 8. However, the expense of methyl-t-butylamine led us to vary the synthesis of 8 . Thus, amination of 6 with $t$ butylamine/n-BuLi gave amide $\mathbf{9}$ in $79 \%$ yield. Sequential two-step methylation of $\mathbf{9}$ to $\mathbf{1 0}$ and then to $\mathbf{8}$ was accomplished in $81 \%$ overall yield. Amide $\mathbf{8}$ was identical as prepared by both methods (Scheme 2).

Our approach to the conversion of amide 8 to lactam 4 was predicated on a radical cyclization methodology that we reported in a similar system some years ago (Scheme 3). ${ }^{21}$ Thus, lithiation at C-2 of amide 8 followed by quenching with $\mathrm{BrCl}_{2} \mathrm{CCCl}_{2} \mathrm{Br}^{22}$ gave the expected 2-bromoindole $\mathbf{1 1}$ in $86 \%$ yield. Treatment of $\mathbf{1 1}$ with tri-n-butyltin hydride and AIBN in toluene afforded the cyclized indoline $\mathbf{1 5}$ (51\% yield) along with the debrominated indole 8 ( $22 \%$ yield). This reaction involves bromine abstraction to give the 2indolyl radical 12 , which abstracts a methyl hydrogen $(1,5-\mathrm{H})$ to give the $\alpha$-amidoyl radical 13 . This radical cyclizes (5-endo-trig) to the indole C-2 position giving the product $\mathbf{1 5}$ after hydrogen atom abstraction by $\mathbf{1 4}$. The relative lability of 15 , although fully characterized, precluded forming crystals suitable for X-ray analysis. Indeed, prolonged exposure of $\mathbf{1 5}$ to air led to a blue-colored solid. Dehydrogenation of $\mathbf{1 5}$ to the known $\mathbf{4}$ was accomplished in $90 \%$ yield using $\mathrm{Pd} / \mathrm{C}$ in refluxing xylene. ${ }^{23}$ Interestingly, other oxidation methods to install the indole double bond in indoline $\mathbf{1 5}$ resulted in no oxidation and only starting material was recovered (e.g. DDQ, 
chloranil, NBS, $\mathrm{PdCl}_{2}$, air/DMSO). Reduction of 4 with DIBAL according to the procedure of $\mathrm{Kreher}^{11}$ gave pyrrolo[3,4-b]indole 5 in $66 \%$ yield.
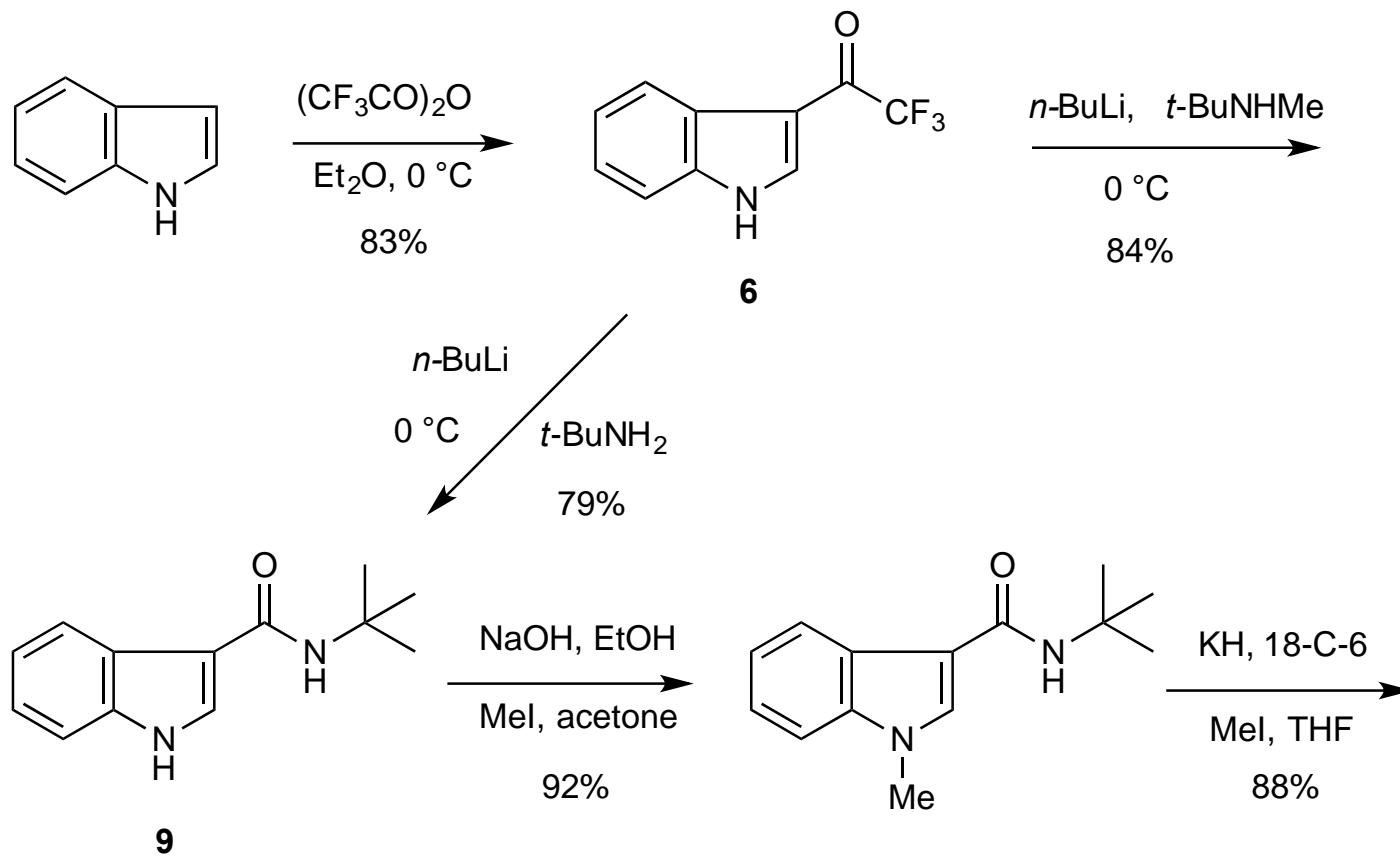<smiles>CN(C(=O)c1c[nH]c2ccccc12)C(C)(C)C</smiles><smiles>CCON=CC(C)C(=O)OC</smiles>

\section{Scheme 2}<smiles>CN(C(=O)c1cn(C)c2ccccc12)C(C)(C)C</smiles>

8<smiles>CCCN(C(=O)CSc1ccccc1)C(C)(C)C</smiles>

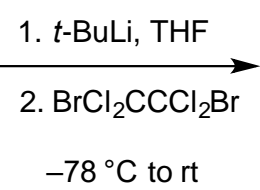

$86 \%$<smiles>CC(C)(C)N(C(=O)c1c(Br)n([N+](=O)[O-])c2ccccc12)C(C)(C)C</smiles>

11

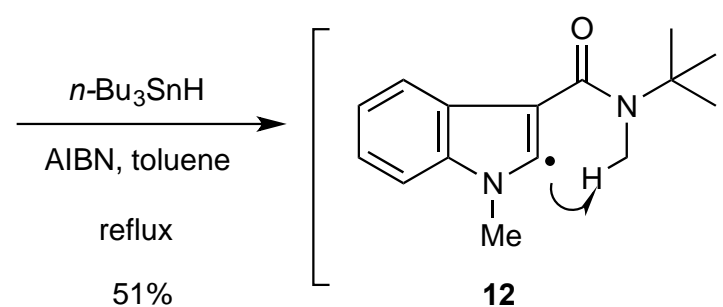

13

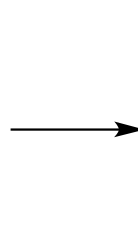

4<smiles>CN1c2ccccc2[C@H]2CN(C(C)(C)C)CC21</smiles>

14<smiles>CN1c2ccccc2C2C(=O)N(C(C)(C)C)C[C@H]21</smiles>

15

$(+22 \% 8)$

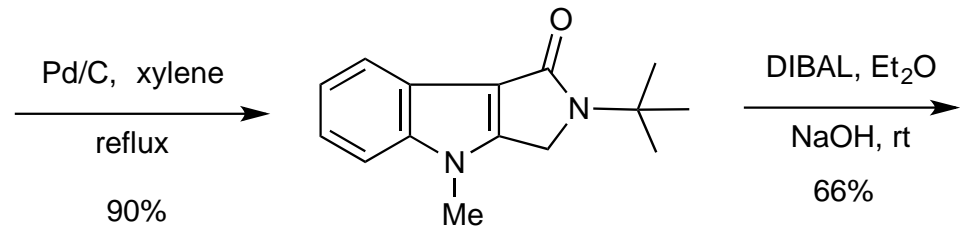

(ref. 11)<smiles>Cn1c2ccccc2c2cn(C(C)(C)C)cc21</smiles>

5

\section{Scheme 3}


An important extension of our methodology is that $\mathrm{LiAlH}_{4}$ reduction of pyrrolo[3,4-b]indolones like 4 should yield the corresponding 1,2,3,4-tetrahydropyrrolo[3,4-b]indole, as shown by Welch. ${ }^{7}$ Thus, we have reported previously that the latter can be oxidized to the pyrrolo[3,4-b]indole ring system, albeit with a different indole $N$-protecting group (Scheme 4). ${ }^{4}$<smiles>[R]N1Cc2c(n(S(=O)(=O)O)c3ccccc23)C1</smiles>

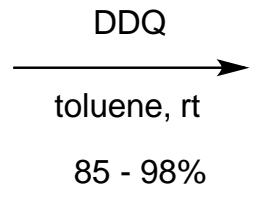<smiles>[R]n1cc2c3ccccc3n(S(=O)(=O)O)c2c1</smiles>
$\mathrm{R}=\mathrm{Bn}, \mathrm{i}-\mathrm{Pr}, \mathrm{t}-\mathrm{Bu}, 4-\mathrm{OMeBn}$ (ref. 4)

\section{Scheme 4}

It should be noted that other syntheses of pyrrolo[3,4- $b]$ indolones and pyrrolo[3,4- $b]$ indolines have been reported in recent years, ${ }^{24-27}$ but which do not involve a radical cyclization/dehydrogenation methodology. These are shown in Scheme 5.<smiles>CCOC(=O)N1CCC(=NNc2ccc(C)cc2)C1</smiles><smiles>CCOC(=O)N1Cc2[nH]c3ccc(C)cc3c2C1</smiles>

ref. 24<smiles>[R]C(N)c1c(C(=O)O)[nH]c2ccccc12</smiles>

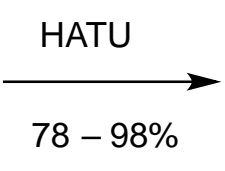<smiles>[R]C1c2c([nH]c3ccccc23)C(=O)N1[R]</smiles>

ref. 25<smiles>[Y5]n1cc([N+](=O)[O-])c2ccccc21</smiles><smiles>[R]C=NC(=O)OC</smiles>

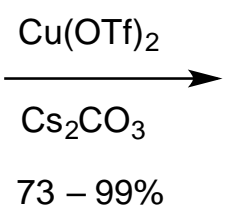<smiles>[R]C1N[C@H](C(C)=O)[C@]2([N+](=O)[O-])c3ccccc3N([As])[C@]12[2H]</smiles><smiles>Cc1[nH]c2ccccc2c1C</smiles><smiles>[R]OC(=O)OCCCCCCCOC(C)=O</smiles><smiles>[R]C1([R])N([I-])C(c2ccccc2)[C@@]2(C)c3ccccc3N[C@]12C</smiles>

ref. 27

\section{Scheme 5}




\section{Conclusions}

In conclusion, we have described a new approach to the pyrrolo[3,4-b]indole ring system that involves pyrrolo[3,4-b]indol-1(2H)one precursors that were initially employed by Welch and Kreher to synthesize pyrrolo[3,4-b]indoles by hydride reduction. Our new synthesis of pyrrolo[3,4-b]indol-1(2H)ones is atom economical and utilizes indole and aliphatic amines as the key ingredients, thus avoiding the necessity of preparing substituted 2,4-pyrrolidinediones that are required for a Fischer indole synthesis strategy.

\section{Experimental Section}

General. Melting points were determined on a Laboratory Devices Mel Temp capillary melting point apparatus, in open capillaries and are uncorrected. Thin layer chromatography (TLC) was performed on Whatman brand $20 \times 20 \mathrm{~cm}$ polyester backed silica plates with fluorescent indicator. Plates were visualized by $254 \mathrm{~nm}$ UV light. Alternative visualization was accomplished by dipping the plate into a solution of ceric ammonium sulfate in $10 \%$ aqueous $\mathrm{H}_{2} \mathrm{SO}_{4}$ then drying. Flash chromatography was carried out using Silicycle ultra pure silica gel 60A (Angstrom). ${ }^{1} \mathrm{H}(300 \mathrm{MHz}),{ }^{13} \mathrm{C}(75 \mathrm{MHz})$, and ${ }^{19} \mathrm{~F}(282.2 \mathrm{MHz}) \mathrm{NMR}$ spectra were recorded on a Varian XL-300 Fourier transform spectrometer unless otherwise indicated (by frequency) in which they were recorded on a Varian Unity plus spectrometer: ${ }^{1} \mathrm{H}(500 \mathrm{MHz})$ and ${ }^{13} \mathrm{C}(125 \mathrm{MHz})$. The chemical shifts are reported in $\delta(\mathrm{ppm})$ using the $\delta 7.27$ signal of $\mathrm{CHCl}_{3}\left({ }^{1} \mathrm{H}-\mathrm{NMR}\right)$ and the $\delta 77.23$ signal of $\mathrm{CDCl}_{3}\left({ }^{13} \mathrm{C}-\right.$ $\mathrm{NMR}$ ), the $\delta 4.87$ signal of $\mathrm{CD}_{3} \mathrm{OH}\left({ }^{1} \mathrm{H}-\mathrm{NMR}\right)$ and the $\delta 49.15$ signal of $\mathrm{CD}_{3} \mathrm{OD}\left({ }^{13} \mathrm{C}-\mathrm{NMR}\right)$, the $\delta 2.51$ signal of $\left(\mathrm{CH}_{3}\right)_{2} \mathrm{SO}\left({ }^{1} \mathrm{H}-\mathrm{NMR}\right)$ and the $\delta 39.50$ signal of $\left(\mathrm{CD}_{3}\right)_{2} \mathrm{SO}\left({ }^{13} \mathrm{C}-\mathrm{NMR}\right)$, or the $\delta 2.05$ signal of $\mathrm{CO}\left(\mathrm{CD}_{3}\right) \mathrm{CD}_{2} \mathrm{H}\left({ }^{1} \mathrm{H}-\right.$ $\mathrm{NMR}$ ) and $\delta 29.92$ signal of $\mathrm{CO}\left(\mathrm{CD}_{3}\right)_{2}\left({ }^{13} \mathrm{C}-\mathrm{NMR}\right)$ and the 0.00 signal of $\mathrm{CFCl}_{3}$ (Freon 11) $\left({ }^{19} \mathrm{~F} \mathrm{NMR}\right)$ as internal standards. The apparent multiplicity ( $\mathrm{s}=$ singlet, $\mathrm{d}=$ doublet, $\mathrm{t}=$ triplet, $\mathrm{q}=$ quartet, $\mathrm{m}=$ multiplet, $\mathrm{b}=$ broad), the number of protons, and the coupling constants (in $\mathrm{Hz}$ ) are reported where appropriate. Infrared spectra (IR) were recorded with a Perkin Elmer Series 1600 FTIR spectrophotometer and are referenced to the 1601 $\mathrm{cm}^{-1}$ band of polystyrene. IR spectra were obtained using either neat compounds (film) or solid potassium bromide pellets $(\mathrm{KBr})$ and are reported in reciprocal centimeters. Ultraviolet (UV) spectra were recorded on a Hewlett-Packard 8451A Diode Array UV spectrophotometer and are reported in nanometers. Low-resolution mass spectra and high-resolution mass spectrometry (HRMS) were also performed at the University of Illinois (Urbana-Champaign) mass spectrometry laboratory. Elemental analyses were performed by Atlantic Microlab Inc. (Norcross, GA). Tetrahydrofuran (THF) was freshly distilled from sodium/benzophenone under $\mathrm{N}_{2}$. All amines and dichloromethane $\left(\mathrm{CH}_{2} \mathrm{Cl}_{2}\right)$ were distilled in the presence of calcium hydride. All alkyllithium reagents were standardized prior to use by titration against diphenylacetic acid in dilute THF. Azobisisobutyronitrile (AIBN) was recrystallized from ethanol. $\mathrm{N}$-Bromosuccinimide was recrystallized prior to use from water and dried in vacuo in the presence of phosphorus pentoxide. Potassium hydride (KH) was purchased from Aldrich as a $35 \%$ dispersion in mineral oil. Sodium hydride $(\mathrm{NaH})$ was purchased from Acros as a $60 \%$ dispersion in mineral oil. The hydrides were washed with hexanes under $\mathrm{N}_{2}$ to remove the mineral oil and then dried under vacuum. 1,2-Dibromo-1,1,2,2-tetrachloroethane $\left(\mathrm{BrCl}_{2} \mathrm{CCCl}_{2} \mathrm{Br}\right)$ was dried by dissolving the white solid in ether, drying over sodium sulfate, filtering under gravity, and removing the solvent in vacuo, prior to use. Unless otherwise indicated, all other reagents and solvents were purchased from commercial sources and were used without further purification. Inert atmospheres of nitrogen or argon were predried by flow through a column of Drierite 4 mesh with indicator. All reactions were done under a positive flow of nitrogen unless otherwise stated. Degassing was accomplished with a Firestone valve using the freeze, pump, 
and thaw method with argon. All references to "water" or " $\mathrm{H}_{2} \mathrm{O}$ " correspond to reverse osmosis deionized (RODI) water. "Brine" is a saturated aqueous sodium chloride solution. All volume descriptions for extractions and washes are approximate. "In vacuo" refers to solvent removal first by rotary evaporation followed by a lower pressure environment ( $\leq 0.2$ Torr). Reaction temperatures ranging between $-75{ }^{\circ} \mathrm{C}$ and $-40{ }^{\circ} \mathrm{C}$ were achieved using a $\mathrm{CO}_{2}$ /isopropanol bath. Reaction temperatures ranging between $0{ }^{\circ} \mathrm{C}$ and $10{ }^{\circ} \mathrm{C}$ were achieved using a ice/sodium chloride bath. Anhydrous reactions were performed with glassware dried for $24 \mathrm{~h}$ at a temperature of $120{ }^{\circ} \mathrm{C}$ or greater then assembled hot and cooled under an atmosphere of nitrogen. Alternatively, glassware was assembled, flame dried, cooled under an atmosphere of nitrogen, and the drying/cooling process was repeated.

2,2,2-Trifluoro-1-(1H-indol-3-yl)ethan-1-one (6). This compound was prepared according to the procedure of Mackie. ${ }^{19}$ To a stirred solution of trifluoroacetic anhydride $\left(11.6 \mathrm{~mL}, 82.1 \mathrm{mmol}, 2.4\right.$ eq.) in Et ${ }_{2} \mathrm{O}(85 \mathrm{~mL})$ at $0{ }^{\circ} \mathrm{C}$ was added a solution of indole $\left(4.0 \mathrm{~g}, 34.2 \mathrm{mmol}, 1 \mathrm{eq}\right.$.) in $\mathrm{Et}_{2} \mathrm{O}(24 \mathrm{~mL})$ over $1 \mathrm{~h}$ via an addition funnel. The solution was stirred at $0{ }^{\circ} \mathrm{C}$ for $8 \mathrm{~h}$. The $\mathrm{Et}_{2} \mathrm{O}$ solution was washed with saturated $\mathrm{NaHCO}_{3}(3 \times 100 \mathrm{~mL})$ and $\mathrm{H}_{2} \mathrm{O}$ $(2 \times 75 \mathrm{~mL})$. The organic layers were combined, dried $\left(\mathrm{Na}_{2} \mathrm{SO}_{4}\right)$, and concentrated in vacuo to give a white solid which was recrystallized from $\mathrm{Et}_{2} \mathrm{O}$ to give 6 (6.02 g, 83\%) as white crystals: $\mathrm{mp} 209-210{ }^{\circ} \mathrm{C}$ (lit. ${ }^{19} \mathrm{mp} 208{ }^{\circ} \mathrm{C}$ ); ${ }^{1} \mathrm{H}-\mathrm{NMR}\left(\mathrm{CDCl}_{3}\right) \delta 11.6(\mathrm{~s}, 1 \mathrm{H}), 8.36(\mathrm{~m}, 1 \mathrm{H}), 8.29(\mathrm{~m}, 1 \mathrm{H}), 7.58(\mathrm{~m}, 1 \mathrm{H}), 7.30(\mathrm{~m}, 2 \mathrm{H}) ;{ }^{13} \mathrm{C}-\mathrm{NMR}\left(\mathrm{CO}\left(\mathrm{CD}_{3}\right)_{2}\right) \delta$ $205.9,136.7,126.5,124.7,123.7,121.9,119.5,115.6,112.9,110.1 ;{ }^{19} \mathrm{~F}-\mathrm{NMR}\left(\mathrm{CFCl}_{3}\right) \delta-73.4$.

$\boldsymbol{N}$-(tert-Butyl)- $\mathbf{N}$-methyl-1H-indole-3-carboxamide (7). To a stirred solution of $t$-butylmethylamine $(2.8 \mathrm{~mL}$, $23.5 \mathrm{mmol}, 5$ eq. $)$, in THF $(40 \mathrm{~mL})$ at $0{ }^{\circ} \mathrm{C}$ under nitrogen was added slowly $n$-BuLi $(9.4 \mathrm{~mL}, 23.5 \mathrm{mmol}, 2.5 \mathrm{M}$ in hexanes, 5 eq.). The solution was stirred at $0{ }^{\circ} \mathrm{C}$ for $2 \mathrm{~h}$. To the anion was added 3-trifluoroacetylindole (6) (1.0 $\mathrm{g}, 4.69 \mathrm{mmol}, 1 \mathrm{eq}$.) in THF $(40 \mathrm{ml})$ at $0{ }^{\circ} \mathrm{C}$. The reaction mixture was allowed to gradually warm to $\mathrm{rt}$ over $18 \mathrm{~h}$ then poured onto ice $\mathrm{H}_{2} \mathrm{O}(75 \mathrm{~mL})$ and stirred for $4 \mathrm{~h}$. The aqueous solution was extracted with $\mathrm{CH}_{2} \mathrm{Cl}_{2}(4 \times 75$ $\mathrm{mL})$. The organic extracts were combined, washed with brine $(2 \times 50 \mathrm{~mL})$, dried $\left(\mathrm{Na}_{2} \mathrm{SO}_{4}\right)$, and concentrated in vacuo to give a yellow oil. This was purified by flash chromatography (2:1 hexanes: EtOAc) to give 7 as a yellow solid (0.91 g, 84\%): ${ }^{1} \mathrm{H}-\mathrm{NMR}\left(\mathrm{CDCl}_{3}\right) \delta 9.44$ (bs, $\left.1 \mathrm{H}\right), 7.65-7.68(\mathrm{~m}, 1 \mathrm{H}), 7.32-7.35(\mathrm{~m}, 2 \mathrm{H}), 7.14-7.21(\mathrm{~m}, 2 \mathrm{H})$, $3.03(\mathrm{~s}, 3 \mathrm{H}), 1.57(\mathrm{~s}, 9 \mathrm{H}) ;{ }^{13} \mathrm{C}-\mathrm{NMR}\left(\mathrm{CDCl}_{3}\right) \delta 169.6,135.7,127.8,125.1,122.3,120.7,120.4,114.9,111.8,56.3$, 35.2, 27.9; IR (KBr) 3444, 3167, 2945, 1587, 1536, 1446, 1123, $1011 \mathrm{~cm}^{-1}$; UV (95\% EtOH) $\delta_{\max } 296 \mathrm{~nm} . ; \mathrm{MS} \mathrm{m} / z$ $230\left(\mathrm{M}^{+}\right), 215,144,116,89,72(100 \%)$. An analytical sample was obtained via iterative recrystallizations from $\mathrm{CH}_{2} \mathrm{Cl}_{2}$ /hexanes: mp 220-222 ${ }^{\circ} \mathrm{C}$. Anal. Calcd for $\mathrm{C}_{14} \mathrm{H}_{18} \mathrm{~N}_{2} \mathrm{O}: \mathrm{C}, 73.01 ; \mathrm{H}, 7.88 ; \mathrm{N}, 12.16$. Found: $\mathrm{C}, 72.80 ; \mathrm{H}$, 7.82; N, 12.08.

$\mathbf{N}$-(tert-Butyl)-N,1-dimethyl-1H-indole-3-carboxamide (8), Method A. To a stirred suspension of $\mathrm{NaOH}(78.9$ $\mathrm{mg}, 1.97 \mathrm{mmol}, 1.3$ eq.) in $\mathrm{EtOH}(50 \mathrm{~mL}$ ) was added the amide 7 (349.1 mg, $1.52 \mathrm{mmol}, 1$ eq.) neat. The solution was stirred for $2 \mathrm{~h}$ at $\mathrm{rt}$ to allow for complete dissolution. The EtOH was removed under reduced pressure, and the residue was dissolved in acetone $(25 \mathrm{~mL})$. The suspension was stirred for 5 min, treated with Mel $(0.1 \mathrm{~mL}, 1.52 \mathrm{mmol}, 1$ eq.) and stirred overnight at rt (ca. $8 \mathrm{~h})$. The solution was filtered under gravity, and the filtrate was then concentrated in vacuo to give a yellow oil. The oil was the triturated repeatedly with $\mathrm{Et}_{2} \mathrm{O}$ to yield 8 as a light yellow solid (359 mg, 97\%). The solid was homologous by TLC and ${ }^{1} \mathrm{H}-\mathrm{NMR}$. All spectral data was identical to those of 8 prepared by Method B (vide infra).

$\boldsymbol{N}$-(tert-Butyl)-1H-indole-3-carboxamide (9). To a stirred solution of $t$-butylamine $(16.4 \mathrm{~mL}, 157 \mathrm{mmol}, 5 \mathrm{eq}$.), in THF (56 mL) at $-78{ }^{\circ} \mathrm{C}$ under nitrogen was added slowly $n$-BuLi ( $62.6 \mathrm{~mL}, 157 \mathrm{mmol}, 2.5 \mathrm{M}$ in hexanes, 5 eq.). The solution was stirred at $-78^{\circ} \mathrm{C}$ for $1 \mathrm{~h}$. To the anion was added a solution of 3-trifluoroacetylindole (6) (6.67 $\mathrm{g}, 31.3 \mathrm{mmol}, 1$ eq.) in THF $(50 \mathrm{~mL})$ at $0{ }^{\circ} \mathrm{C}$. The reaction mixture was allowed to gradually warm to $\mathrm{rt}$ over 12 h. This was poured onto ice $\mathrm{H}_{2} \mathrm{O}(100 \mathrm{~mL})$ and stirred for $2 \mathrm{~h}$ before the aqueous solution was extracted with 
$\mathrm{CH}_{2} \mathrm{Cl}_{2}(1 \times 65 \mathrm{~mL})$. The entire solution was filtered through Celite ${ }^{\circledR}$ to separate the emulsion that formed. The aqueous layer was further extracted with $\mathrm{CH}_{2} \mathrm{Cl}_{2}(3 \times 65 \mathrm{~mL})$. The organic layers were combined, washed with brine $(1 \times 100 \mathrm{~mL})$, dried $\left(\mathrm{Na}_{2} \mathrm{SO}_{4}\right)$, and concentrated in vacuo to give a dark yellow oil. The oil was purified by flash chromatography (2:1 hexanes: EtOAc) to give 9 as a pale yellow solid $(6.76 \mathrm{~g}, 79 \%):{ }^{1} \mathrm{H}-\mathrm{NMR}(\mathrm{CDCl}) \delta$ $9.60(\mathrm{~s}, 1 \mathrm{H}), 7.89-7.85(\mathrm{~m}, 1 \mathrm{H}), 7.68(\mathrm{~d}, 1 \mathrm{H}, J 2.8 \mathrm{~Hz}), 7.41-742(\mathrm{~m}, 1 \mathrm{H}), 7.26-7.21(\mathrm{~m}, 2 \mathrm{H}), 5.94(\mathrm{~s}, 1 \mathrm{H}), 1.55(\mathrm{~s}$, 9H); ${ }^{13} \mathrm{C}-\mathrm{NMR}\left(\mathrm{CDCl}_{3}\right) \delta 165.5,136.7,128.5,124.3,122.5,121.3,119.1,113.0,112.5,51.5,29.3$; IR (film) 3399, 3231, 2964, 1627, 1538, 1449, 1231, $737 \mathrm{~cm}^{-1}$; MS m/z $216\left(\mathrm{M}^{+}\right), 161,144,116,89$. An analytical sample was obtained via iterative recrystallizations from Et $2 \mathrm{O}: \mathrm{mp} 188-190{ }^{\circ} \mathrm{C}$. Anal. Calcd for $\mathrm{C}_{13} \mathrm{H}_{16} \mathrm{~N}_{2} \mathrm{O}: \mathrm{C}, 72.19 ; \mathrm{H}, 7.46$; N, 12.95. Found: C, 72.14; H, 7.41; N, 12.87.

$\mathbf{N}$-(tert-Butyl)-1-methyl-1H-indole-3-carboxamide (10). To a stirred suspension of $\mathrm{NaOH}(1.27 \mathrm{~g}, 31.8 \mathrm{mmol}$, 1.3 eq.) in $\mathrm{EtOH}(100 \mathrm{~mL}$ ) was added amide 9 (5.28 g, $24.4 \mathrm{mmol}, 1$ eq.) neat. The solution was stirred for $2 \mathrm{~h}$ at $\mathrm{rt}$. The $\mathrm{EtOH}$ was removed under reduced pressure, and the residue was dissolved in acetone $(100 \mathrm{~mL})$. The suspension was stirred for $15 \mathrm{~min}$, treated with Mel (2 mL, $31.8 \mathrm{mmol}, 1.3$ eq.) and stirred overnight. The yellow solution was filtered under gravity, and the filtrate was concentrated in vacuo to give a pale yellow oil. The oil was triturated repeatedly with $\mathrm{Et}_{2} \mathrm{O}$ to yield $5.19 \mathrm{~g}$ of 10 as a white solid $(92 \%):{ }^{1} \mathrm{H}-\mathrm{NMR}\left(\mathrm{CDCl}_{3}\right) \delta 7.90$ $(\mathrm{m}, 1 \mathrm{H}), 7.62(\mathrm{~s}, 1 \mathrm{H}), 7.37-7.23(\mathrm{~m}, 3 \mathrm{H}), 5.82(\mathrm{~s}, 1 \mathrm{H}), 3.80(\mathrm{~s}, 3 \mathrm{H}), 1.52(\mathrm{~s}, 9 \mathrm{H}) ;{ }^{13} \mathrm{C}-\mathrm{NMR}\left(\mathrm{CDCl}_{3}\right) \delta 164.7,137.3$, 132.3, 125.2, 122.4, 121.3, 119.8, 112.2, 110.1, 51.4, 33.2, 29.3; IR (KBr) 3444, 3367, 3100, 2956, 1622, 1533, 1456, 1278, 1111, $744 \mathrm{~cm}^{-1}$; UV (95\% EtOH) $\delta_{\max } 298$ nm; MS m/z $230\left(\mathrm{M}^{+}\right), 174,158(100 \%), 130,103,77,42$. An analytical sample was obtained via iterative recrystallizations from $\mathrm{Et}_{2} \mathrm{O}: \mathrm{mp} 200-201.5{ }^{\circ} \mathrm{C}$. Anal. Calcd for $\mathrm{C}_{14} \mathrm{H}_{18} \mathrm{~N}_{2} \mathrm{O}$ : C, 73.01; $\mathrm{H}, 7.88 ; \mathrm{N}, 12.16$. Found: $\mathrm{C}, 72.92 ; \mathrm{H}, 7.86 ; \mathrm{N}, 12.08$.

$\mathbf{N}$-(tert-Butyl)-N,1-dimethyl-1H-indole-3-carboxamide (8), Method B. To a stirred suspension of KH (117 mg, $2.93 \mathrm{mmol}, 1.2$ eq.) in THF (10 mL) was added 18-crown-6 (775 mg, $2.93 \mathrm{mmol}, 1.2$ eq.) neat. The suspension was stirred at $0{ }^{\circ} \mathrm{C}$ under nitrogen for $1 \mathrm{~h}$, at which time was added amide 10 (561.3 mg, $2.44 \mathrm{mmol}, 1$ eq.) in THF (34 mL) via an addition funnel. The solution was stirred at $0{ }^{\circ} \mathrm{C}$ for $1 \mathrm{~h}$, treated with Mel $(0.2 \mathrm{~mL}, 2.93$ mmol, 1.2 eq.), and stirred overnight. The solution was poured onto ice $\mathrm{H}_{2} \mathrm{O}(100 \mathrm{~mL})$ and stirred thoroughly. The white solid that formed was collected by vacuum filtration and dried under vacuum to give the amide $\mathbf{8}$ as a white solid (516 mg, 88\%). The filtrate was extracted with $\mathrm{CH}_{2} \mathrm{Cl}_{2}(3 \times 65 \mathrm{~mL}$ ) and the organic extracts were washed with brine $(2 \times 50 \mathrm{~mL})$, dried $\left(\mathrm{Na}_{2} \mathrm{SO}_{4}\right)$, and concentrated in vacuo to give a yellow oil. Trituration of the oil with $\mathrm{Et}_{2} \mathrm{O}$ gave the desired amide 8 as a white solid $(12.5 \mathrm{mg})$. Total yield of 8 was $88 \%$ (529 mg). Both solids were homologous by TLC and ${ }^{1} \mathrm{H}-\mathrm{NMR} ;{ }^{1} \mathrm{H}-\mathrm{NMR}\left(\mathrm{CDCl}_{3}\right) \delta 7.68-7.71\left(\mathrm{dd}, 1 \mathrm{H}, \mathrm{J}^{\prime} 1.4 \mathrm{~Hz}, \mathrm{~J}^{\prime \prime} 7.3 \mathrm{~Hz}\right), 7.46$ (s, $1 \mathrm{H})$, 7.19-7.35 (m, 3H), $3.81(\mathrm{~s}, 3 \mathrm{H}), 3.06(\mathrm{~s}, 3 \mathrm{H}), 1.57(\mathrm{~s}, 9 \mathrm{H}) ;{ }^{13} \mathrm{C}-\mathrm{NMR}\left(\mathrm{CDCl}_{3}\right) \delta 169.4,136.8,132.4,126.1$, 122.4, 121.2, 121.0, 114.4, 109.9, 56.4, 35.5, 33.4, 28.1; IR (KBr) 3458, 3113, 2975, 1627, 1533, 1474, 1363, $325,1238,1132,1086 \mathrm{~cm}^{-1}$; UV $\lambda_{\max }(95 \% \mathrm{EtOH}) 218,264,290,332,348 \mathrm{~nm}$. An analytical sample of 8 was obtained via iterative recrystallizations from $\mathrm{Et}_{2} \mathrm{O}$ : $\mathrm{mp} 165-166^{\circ} \mathrm{C}$. Anal. Calcd for $\mathrm{C}_{15} \mathrm{H}_{20} \mathrm{~N}_{2} \mathrm{O}: \mathrm{C}, 73.74 ; \mathrm{H}, 8.25$; N, 11.47. Found: C, 73.67; H, 8.30; N, 11.44.

2-Bromo- $\boldsymbol{N}$-(tert-butyl)-N,1-dimethyl-1H-indole-3-carboxamide (11). To a stirred solution of the methylated amide 8 (816 mg, $3.34 \mathrm{mmol}, 1$ eq.) in THF (40 mL) at $-78{ }^{\circ} \mathrm{C}$ was added slowly $t$-BuLi (3.0 mL, $5.01 \mathrm{mmol}, 1.7$ $M$ in hexanes, 1.5 eq.). The solution was stirred at $-78{ }^{\circ} \mathrm{C}$ for $1 \mathrm{~h}$, then warmed to rt over 30 min before recooling to $-78{ }^{\circ} \mathrm{C}$. At this time the anion was treated with dried 1,2-dibromo-1,1,2,2-tetrachloroethane (1.63 g, $5.01 \mathrm{mmol}, 1.5$ eq.) in THF $(20 \mathrm{~mL})$. The solution warmed to rt overnight then poured onto ice $\mathrm{H}_{2} \mathrm{O}(100 \mathrm{~mL})$ and stirred for $2 \mathrm{~h}$. No precipitate formed upon stirring. The aqueous layer was extracted with $\mathrm{CH}_{2} \mathrm{Cl}_{2}(4 \times 50$ $\mathrm{mL})$. The organic layers were combined, washed with brine $(1 \times 100 \mathrm{~mL})$, dried $\left(\mathrm{Na}_{2} \mathrm{SO}_{4}\right)$, and concentrated in vacuo to give a brown oil. Purification using flash column chromatography (2:1 hexanes: EtOAc) gave bromide 11 as a yellow solid (887 mg, 86\%); ${ }^{1} \mathrm{H}-\mathrm{NMR}\left(\mathrm{CDCl}_{3}\right) \delta 7.57-7.71\left(\mathrm{dt}, 1 \mathrm{H}, \mathrm{J}^{\prime} 1.2 \mathrm{~Hz}, \mathrm{~J}^{\prime \prime} 8.0 \mathrm{~Hz}\right), 7.14-7.34(\mathrm{~m}, 3 \mathrm{H})$, 
$3.76(\mathrm{~s}, 3 \mathrm{H}), 2.96(\mathrm{~s}, 3 \mathrm{H}), 1.57(\mathrm{~s}, 9 \mathrm{H}) ;{ }^{13} \mathrm{C}-\mathrm{NMR}\left(\mathrm{CDCl}_{3}\right) \delta 167.1,136.4,125.8,122.5,121.0,119.6,114.7,114.2$, 109.5, 56.5, 34.2, 31.5, 28.0; IR (film) 3456, 3052, 2979, 1627, 1516, 1466, 1386, 1386, $13321265 \mathrm{~cm}^{-1}$; UV $\lambda_{\max }\left(95 \%\right.$ EtOH) 212, 266, 290, 332, $348 \mathrm{~nm}$; MS m/z $323\left(\mathrm{M}^{+}\right)$, 307, 268, 236 (100\%), 208, 169, 158, 129. An analytical sample of $\mathbf{1 1}$ was obtained via iterative recrystallizations from $\mathrm{Et}_{2} \mathrm{O}: \mathrm{mp} 105-106{ }^{\circ} \mathrm{C}$. Anal. Calcd for $\mathrm{C}_{15} \mathrm{H}_{19} \mathrm{BrN}_{2} \mathrm{O}: \mathrm{C}, 55.74 ; \mathrm{H}, 5.92 ; \mathrm{N}, 8.67 ; \mathrm{Br}, 24.72$. Found: $\mathrm{C}, 56.13 ; \mathrm{H}, 5.94 ; \mathrm{N}, 8.64 ; \mathrm{Br}, 24.42$.

2-(tert-Butyl)-4-methyl-3,3a,4,8b-tetrahydropyrrolo[3,4-b]indol-1(2H)-one (15). To a refluxing solution of bromide 11 (869 mg, $2.69 \mathrm{mmol}, 1$ eq.) in degassed toluene $(60 \mathrm{~mL})$ under $\mathrm{Ar}$, was added $n-\mathrm{Bu}_{3} \mathrm{SnH}(0.9 \mathrm{~mL}$, $3.23 \mathrm{mmol}, 1.2$ eq.) and AIBN ( $88.0 \mathrm{mg}, 0.54 \mathrm{mmol}, 0.2$ eq.) in degassed toluene $(20 \mathrm{~mL})$ dropwise over $24 \mathrm{~h}$ via a Kontes ${ }^{\circledR}$ constant addition funnel. The solution was refluxed for a total of $48 \mathrm{~h}$ then cooled to $\mathrm{rt}$. The solvent was removed in vacuo and the resulting residue was chromatographed (2:1 hexanes: EtOAc) to give dihydroindole 15 (334 mg) in 51\% yield and the reduced compound 8 in 22\% yield (144 mg) as pale yellow solids; ${ }^{1} \mathrm{H}-\mathrm{NMR}\left(\mathrm{CDCl}_{3}\right) \delta 7.31-7.34(\mathrm{~d}, 1 \mathrm{H}, J 7.3 \mathrm{~Hz}), 7.08-7.13\left(\mathrm{td}, 1 \mathrm{H}, J^{\prime} 1.1 \mathrm{~Hz}, J^{\prime \prime} 7.7 \mathrm{~Hz}\right), 6.70-6.73\left(\mathrm{td}, 1 \mathrm{H}, J^{\prime}\right.$ $0.7 \mathrm{~Hz}, J^{\prime \prime} 7.3 \mathrm{~Hz}$ ), 6.41-6.43 (d, 1H, J 7.7 Hz), 4.01-4.07 (qd, 1H, J' 1.5 Hz, J" 9.2 Hz), 3.93-3.95 (d, $\left.1 \mathrm{H}, J 9.2 \mathrm{~Hz}\right)$, 3.66-3.71 (dd, 1H, J' $5.5 \mathrm{~Hz}, J^{\prime \prime} 10.3 \mathrm{~Hz}$ ), 3.56-3.59 (dd, $\left.1 \mathrm{H}, J^{\prime} 1.5 \mathrm{~Hz}, J^{\prime \prime} 10.3 \mathrm{~Hz}\right), 2.80$ (s, 3H), $1.38(\mathrm{~s}, 9 \mathrm{H}) ;{ }^{13} \mathrm{C}-$ NMR $\left(\mathrm{CDCl}_{3}\right) \delta 172.5,152.0,128.4,126.1,124.9,118.6,106.6,63.4,54.3,51.1,50.7,34.4,27.6$; IR (film) 2975, 2877, 2243, 1674, 1607, 1488, 1413, 1365, $1285 \mathrm{~cm}^{-1}$; MS m/z $244\left(\mathrm{M}^{+}\right), 187,158$ (100\%), 144, 131,103, 89, 77. An analytical sample of 15 was obtained via iterative recrystallizations from Et ${ }_{2} \mathrm{O}: \mathrm{mp} 100-100.5^{\circ} \mathrm{C}$. Anal. Calcd for $\mathrm{C}_{15} \mathrm{H}_{18} \mathrm{~N}_{2} \mathrm{O}$ : C, 73.74; $\mathrm{H}, 8.25 ; \mathrm{N}, 11.47$. Found: $\mathrm{C}, 73.83 ; \mathrm{H}, 8.34 ; \mathrm{N}, 11.39$.

2-(tert-Butyl)-4-methyl-3,4-dihydropyrrolo[3,4-b]indol-1(2H)-one (4). To a solution of the dihydroindole 15 (41.5 mg, $0.17 \mathrm{mmol}, 1$ eq.) in xylenes $(5 \mathrm{~mL})$ was added Pd/C (10\% Pd, $40.3 \mathrm{mg}, 0.38 \mathrm{mmol}, 2.2$ eq.). The mixture was heated at reflux for $14 \mathrm{~h}$. No more starting material was present by TLC. The catalyst was removed by filtration through Celite ${ }^{\circledR}$ and washed thoroughly with toluene. The filtrate was collected and concentrated in vacuo to give lactam 4 as a white crystalline solid $(37.2 \mathrm{mg}$ ) in $90 \%$ yield. The solid was homologous by TLC: $\mathrm{mp} 171-172{ }^{\circ} \mathrm{C}$ (lit. $\left.{ }^{11} \mathrm{mp} 175{ }^{\circ} \mathrm{C}\right) ;{ }^{1} \mathrm{H}-\mathrm{NMR}\left(\mathrm{CDCl}_{3}\right) \delta 7.87-7.89\left(\mathrm{dd}, 1 \mathrm{H}, J^{\prime} 1.2 \mathrm{~Hz}, J^{\prime \prime} 7.1 \mathrm{~Hz}\right.$ ), 7.20-7.29 (m, 3H), $4.30(\mathrm{~s}, 2 \mathrm{H}), 3.67(\mathrm{~s}, 3 \mathrm{H}), 1.54(\mathrm{~s}, 9 \mathrm{H}) ;{ }^{13} \mathrm{C}-\mathrm{NMR}\left(\mathrm{CDCl}_{3}\right) \delta 168.6,151.8,142.2,123.0,122.6$, 121.9, 121.0, 120.9, 110.4, 55.1, 43.8, 31.5, 29.2; IR (film) 2977, 2253, 1661, 1560, 1454, 1404, $1344 \mathrm{~cm}^{-1}$.

2-(tert-Butyl)-4-methyl-2,4-dihydropyrrolo[3,4-b]indole (5). This compound was prepared according to the procedure of Kreher. ${ }^{11}$ To a solution of indolone 4 (34.1 mg, 0.14 mmol, 1 eq.) in anhydrous $\mathrm{Et}_{2} \mathrm{O}$ (3 mL) was added dropwise DIBAL solution $(0.16 \mathrm{~mL}, 0.16 \mathrm{mmol}, 1.0 \mathrm{M}$ in hexanes, 1.1 eq.). The solution was stirred for $24 \mathrm{~h}$ at $\mathrm{rt}$. To this was added $10 \% \mathrm{NaOH}(4 \mathrm{~mL})$ and stirred for $1 \mathrm{~h}$. The mixture was extracted repeatedly with $\mathrm{CH}_{2} \mathrm{Cl}_{2}$. The combined organic extracts were dried $\left(\mathrm{MgSO}_{4}\right)$, and concentrated in vacuo to give a yellow solid. Flash column chromatography (4:1 hexanes: EtOAc) gave unchanged 4 (6.4 mg) and pyrroloindole 5 (17.0 mg) as a yellow oil, which turned green on standing. Total yield of 5 based on recovered starting material was $66 \%$ : ${ }^{1} \mathrm{H}-\mathrm{NMR}\left(\mathrm{CDCl}_{3}\right) \delta$ 7.70-7.72 (dd, $\left.1 \mathrm{H}, \mathrm{J}^{\prime} 0.73 \mathrm{~Hz}, \mathrm{~J}^{\prime \prime} 7.7 \mathrm{~Hz}\right), 7.22-7.28(\mathrm{~m}, 1 \mathrm{H}), 7.11-7.14(\mathrm{~m}, 2 \mathrm{H}), 7.00-7.04(\mathrm{td}$, $\left.1 \mathrm{H}, J^{\prime}=1.1 \mathrm{~Hz}, J^{\prime \prime}=7.3 \mathrm{~Hz}\right), 6.58-6.59\left(\mathrm{~d}, 1 \mathrm{H}, J^{\prime}=1.8 \mathrm{~Hz}\right), 3.64(\mathrm{~s}, 3 \mathrm{H}), 1.67(\mathrm{~s}, 9 \mathrm{H}) ;{ }^{13} \mathrm{C}-\mathrm{NMR}\left(\mathrm{CDCl}_{3}\right) \delta 146.4$, $137.8,123.3,121.0,120.3,117.5,115.1,107.7,105.0,91.5,55.9,31.4,31.3$. These data are in agreement with the literature data. ${ }^{11}$

\section{Acknowledgements}

This investigation was supported in part by the National Institutes of Health (GM58601) and by Dartmouth College. 


\section{References}

1. Pelkey, E. T.; Gribble, G. W. Chem. Commun. 1997, 1873.

2. Gribble, G. W.; Pelkey, E. T.; Switzer, F. L. Synlett 1988, 1061.

3. Gribble, G. W.; Pelkey, E. T.; Simon, W. M.; Trujillo, H. A. Tetrahedron 2000, 56, 10133. https://doi.org/10.1016/S0040-4020(00)00858-9

4. Kishbaugh, T. L. S.; Gribble, G. W. Synth. Commun. 2002, 32, 2003. https://doi.org/10.1081/SCC-120004850

5. Pelkey, E. T.; Gribble, G. W. Can. J. Chem. 2006, 84, 1338. https://doi.org/10.1139/v06-075

6. Roy, S.; Kishbaugh, T. L. S.; Jasinski, J. P.; Gribble, G. W. Tetrahedron Lett. 2007, 48, 1313. https://doi.org/10.1016/i.tetlet.2006.12.125

7. Welch, W. M. J. Org. Chem. 1976, 41, 2031. https://doi.org/10.1021/jo00873a033

8. Sha, C.-K.; Chuang, K.-S.; Young, J.-J. J. Chem. Soc., Chem. Commun. 1984, 1552.

9. Sha, C.-K.; Chuang, K.-S.; Wey, S.-J. J. Chem. Soc., Perkin Trans. 1 1987, 977. https://doi.org/10.1021/jo00873a033

10. Sha, C.-K.; Yang, J.-F. Tetrahedron 1992, 48, 10645. https://doi.org/10.1016/S0040-4020(01)88360-5

11. Kreher, R. P.; Dyker, G. Z. Naturforsch Teil B: Chem. Sci. 1987, 42, 473.

12. Dyker, G.; Kreher, R. P. Chem.-Ztg. 1988, 112, 235.

13. Jeevanandam, A.; Srinivasan, P. C. J. Chem. Soc., Perkin Trans. 1 1995, 2663. https://doi.org/10.1039/p19950002663

14. Daly, K.; Nomak, R.; Snyder, J. K. Tetrahedron Lett. 1997, 38, 8611. https://doi.org/10.1016/S0040-4039(97)10312-4

15. Solé, D.; Bennasar, M.-L.; Jiménez, I. Org. Biomol. Chem. 2011, 9, 4535. https://doi.org/10.1039/c1ob05087g

16. Southwick, P. L.; Previc, E. P.; Casanova, Jr., J.; Carlson, E. H. J. Org. Chem. 1956, 21, 1087. https://doi.org/10.1021/jo01116a009

17. Southwick, P. L.; Owellen, R. J. J. Org. Chem. 1960, 25, 1133. https://doi.org/10.1021/jo01077a017

18. Lowe, G. W.; Yeung, H. W. J. Chem. Soc., Perkin Trans. 1 1973, 2907. https://doi.org/10.1039/P19730002907

19. Mackie, R. K.; Mhatre, S.; Tedder, J. M. J. Fluorine Chem. 1977, 10, 437. https://doi.org/10.1016/S0022-1139(00)82425-2

20. Hassinger, H. L.; Soll, R. M.; Gribble, G. W. Tetrahedron Lett. 1998, 39, 3095. https://doi.org/10.1016/S0040-4039(98)00505-X

21. Gribble, G. W.; Fraser, H. L.; Badenock, J. C. Chem. Commun. 2001, 805. https://doi.org/10.1039/b101859k

22. Bergman, J.; Venemalm, L. J. Org. Chem. 1992, 57, 2495. https://doi.org/10.1021/jo00034a058

23. Tanaka, H.; Murakami, Y.; Aizawa, T.; Torii, S. Bull. Chem. Soc. Jpn. 1989, 62, 3742. https://doi.org/10.1246/bcsj.62.3742 
24. Ivachtchenko, A. V.; Frolov, E. B.; Mitkin, O. D.; Tkachenko, S. E.; Khvat, A. V. Chem. Het. Cpds. 2010, 46, 170.

https://doi.org/10.1007/s10593-010-0488-z

25. Ma, F.; Ma, L.; Lei, M.; Hu, L. Monatsch. Chem. 2014, 145, 1035.

https://doi.org/10.1007/s00706-014-1171-3

26. Awata, A.; Arai, T. Angew. Chem. Int. Ed. 2014, 53, 10462.

https://doi.org/10.1002/anie.201405223

27. Liu, H.; Zheng, C.; You, S.-L. Chin. J. Chem. 2014, 32, 709.

https://doi.org/10.1002/cjoc. 201400178 